\title{
GU(U)AM - from declaration to reality
}

Outline: The article seeks to characterise the activity of GUUAM, an organisation of post-Soviet states set up in 1997 comprising Georgia, Ukraine, Uzbekistan (officially withdrew in 2005), Azerbaijan and Moldova, to cooperate on issues of shared importance. After presenting a historical overview of the organisation's beginnings, the author analyses their joint security issues, their dependence on Russian energy sources, and finding ways of diversifying and transmitting key resources. In her reflections on the future of the organisation, she concludes that GUUAM's main policies will remain strictly tied to energy security issues.

Keywords: GUAM, UE, energy security, Organization for Democracy and Economic Development, Transport Corridor Europe-Caucasus-Asia, Intrastate Oil Gas Transport to Europe, Southeast European Law Enforcement Center

\section{THE PAST}

The collapse of the Soviet Union in 1991 spawned a dozen independent states which, having fallen under the dominance of a Russian Federation (RF) faithful to its imperialist traditions, saw their chance for liberation in regional cooperation. It seemed the only rational answer to Russia's attitude towards the newly-founded Commonwealth of Independent States (CIS), based on a "core / peripheries" model, where the peripheries were seen as a sales market for uncompetitive products, a source of cheap resources and an operational/tactical foreground for its defence strategy ${ }^{1}$. In 1994, Georgian president Eduard Shevardnadze brought up the idea of forming a regional organisation responding to the needs

1 Such a model was already considered in 1993. K. Malak, Polityka zagraniczna Rosji w okresie prezydentury Borysa Jelcyna (1991-2000), [in:] p. Kraszewski (ed.), Cywilizacja Rosji imperialnej, Poznań 2002, p. 327. 
of Caucasian and Central Asian states to better integrate with the worldwide economic system. In the case of Azerbaijan, Georgia, Moldova and Ukraine, the origins of their cooperation can be traced back to the 1996 Summit on Conventional Armed Forces in Europe, which took place in Vienna. The four states affirmed their unanimous position on certain key issues and proposed joint initiatives. At the session of the Council of Europe held on October 10, 1997 in Strasbourg, the Presidents of Azerbaijan, Georgia, Moldova and Ukraine determined their common interests and declared their will to intensify mutual relations in political, economic and military matters; they also hailed the prospect of developing such cooperation within the OSCE and other European and Atlantic structures. The new initiative, which took the form of a consultation forum, took its name from the initials of the founding countries. It was envisioned as an organisation based on a community of economic interests ${ }^{2}$. Following consultations of Foreign Ministers, a joint protocol defining the scope of the group's activity was signed in November 1997. The cooperation was to comprise collective political actions with a view to a peaceful settlement of conflicts, the suppression of separatist movements, an intensification of TRACECA ${ }^{3}$ initiatives, and integration with European and Euro-Atlantic structures. These declarations, complemented by the desire to cooperate on the construction of the Caspian pipeline, were reasserted in October 1998 in Washington. Two months later, the GUAM members announced their will to cooperate with the UN and NATO ${ }^{4}$.

The establishment of GUAM was influenced by Russias intensifying pro-integration activity in the CIS sphere, manifested through the signing of successive agreements with Belarus, effectively merging both countries into the Union of Belarus and Russia (later to become the Union State). Since its foundation, the GUAM group has been perceived in the West as an anti-Russian institution. The Swedish expert Robert Larsson adopted this premise in his work Georgia's Search for Security ${ }^{5}$. The Kremlin shared a similar point of view; Konstantin Zatulin, Director of the Institute of CIS Countries in Moscow and Deputy of the State Duma, later summarised Russia's stance in the following words: "After the collapse of Yugoslavia, the West commenced the dissolution of the Commonwealth of Independent States. Such is the purpose of GUAM, an organisation financed by the United States with the sole view

2 Ł. Wróblewski, GUAM-Organizacja na rzecz Demokracji i Rozwoju, http://www.psz.pl/index2. php?option=content\&do_pdf=18id=2907 (accessed on 5 II 2012).

3 TRACECA (Transport Corridor Europe-Caucasus-Asia). Ultimately, the TRACECA network will be connected to the Trans-European-Networks in Turkey, Romania and Ukraine, thus creating a new Intercontinental communication route, J. Brodowski, Wzajemne relacje Federacji Rosyjskiej i Azerbejdżanu w ramach WNP, [in:] E. Cziomer, M. Czajkowski (ed.), Polityka Federacji Rosyjskiej wobec państw członkowskich WNP, Kraków 2006, p. 97.

4 A. Myśliwy, GUUAM - szansa na stabilizację dla "Eurazjatyckich Bałkanów", "Arcana" 2005, no. 3, p. 134.

5 http://pdc.ceu.hu/archive/00004538/01/Robert_Larson_Georgia_Search_for_Security.pdf, pp. 56-57 (accessed on 2 II 2012). 
to weaken the CIS"6. The Russian Federation (RF) perceived the organisation as a threat to the Russian monopoly in the transmission of energy resources, a decentralising factor for the CIS, and the strategic lodgement of the U.S. in the ex-Soviet area $^{7}$. From its inception, GUAM operated with the political and financial support from the United States, as Washington was interested in the development of energy cooperation with countries from the Caspian Sea region ${ }^{8}$. Despite official assertions from GUAM members that the organisation had not been created in opposition to Russia, obvious "anti-Russian elements" can be noticed in its goals and tasks, such as the fight against separatist movements (which are largely supported by Russia). The dependence of all post-Soviet states on Russia in terms of energy sources gives Moscow the possibility to influence the internal and external policies of those republics. The year 1999 proved to be important to GUAM members. In January, their Ministers of Defence held a meeting in Baku to discuss their defence policies ${ }^{9}$. Russia completed the withdrawal of its troops from the Georgian-Turkish border and announced, under Western pressure, at the OSCE summit in Istanbul the withdrawal of all its troops from Georgian territory. On April 2, Georgia, Azerbaijan and Uzbekistan decided not to extend their participation in the Tashkent Treaty, thus opting out of a defence alliance dominated by Russia. In April 1999, GUAM was joined by Uzbekistan, which strongly stressed its desire to participate solely in economic ventures, rejecting all forms of military and political cooperation ${ }^{10}$. During the NATO EAPC summit in Washington on April 24, 1999, the organisation's name was changed to GUUAM. This was followed by a declaration underlining the need to intensify multilateral cooperation, to coordinate the policies within international institutions, to strengthen collaboration within the Partnership for Peace programme and the North-Atlantic Partnership Council, and to advocate the peaceful settlement of conflicts. Preventive action aimed at drug trafficking to areas of conflict was announced, and a common stance regarding the extension and acceleration of work on the Transport Corridor Europe-Caucasus-Asia (dubbed the Silk Road

6 As quoted by M. Przełomiec, Grajmy w GUAM, “OZON”, no. 22 (59) 2006, p. 50. More on the U.S. role in GU(U)AM integration initiative: p. Goble, The United States and GUAM: From Tactic to Partnership, "Central Asia and the Caucasus", 2008, no. 3-4, pp. 156-160.

7 A. Dugin, one of the most famous partisans of neo-Eurasianism, believes that a struggle between two civilisations is taking place in the post-Soviet space: the continental (Russia) and the oceanic (U.S. and its allies). The creation of GUUAM and the support offered to "colour revolutions" aims to let power in post-Soviet republics get seized by elites opposed to Russia's activity within the CIS. According to him, the territories of GUUAM states have become an area of strategic presence of the U.S. and NATO, R. Mazur, Wspólnota Niepodlegtych Państw - integracja czy dezintegracja, [in:] Z. J. Winnicki, W. Baluk, G. Tokarz (ed.), Wybrane problemy badań wschodnich, Wrocław 2007, pp. 181-182. The resemblance of the name and surname of the author of this article is concidental.

8 E. Wyciszkiewicz, Perspektywy rozwoju GUUAM, "Biuletyn Polskiego Instytutu Spraw Międzynarodowych" no. 31(276), April 25, 2005, p. 1393, http://www.pism.pl/files/?id_plik=214 (accessed on 21 II 2012).

9 A. Myśliwy, op. cit., p. 134.

10 Ibid. 
of the 21st Century)—an EU project-was adopted ${ }^{11}$. The tramission of oil from Azerbaijan to the Georgian coast of the Black Sea through the Baku-Supsa pipeline, built by Western companies, was also launched in April ${ }^{12}$.

The GUUAM member states hoped to impose more pressure on the European Union and NATO in order to increase the presence of these organisations in the region, thus limiting Russia's influence. One advantage of the treaty was that its signatories were located in different geopolitical sub-regions. Their common Soviet past also was advantageous to some degree, since they inherited mutually compatible infrastructure (their road and rail networks, vehicles, technology and machinery), facilitating economic exchange and conferring the image of a coherent economic area ${ }^{13}$. Georgia, Azerbaijan and Moldavia have a shared interest in combatting separatist movements-in Southern Ossetia, Abkhazia, Nagorno-Karabakh and Transnistriaand the desire to regain territorial integrity. For Georgia, struck by the reintroduction of visas by Russia in December 2000, which in consequence brought the country's economy to the verge of crisis, the achievement of strict regional cooperation was becoming increasingly crucial.

Aware of the low purchase rate of GUUAM's policies, its members decided, during the UN summit in New York in September 2000, to intensify their cooperation by means of a schedule of regular meetings-in the form of summits-of the heads of states and foreign ministers (at least once a year and twice a year respectively); a Committee of National Coordinators, responsible for the supervision of this collaboration, would also gather every three months. The principle of consensus was adopted in decision-making. The organisation was proclaimed open to all countries recognising and respecting its rules. The main topics discussed were the promotion of international trade and transport, the settlement of local conflicts and the potential admission of new members (Poland, Slovakia, Romania, and Bulgaria). The participants undertook negotiations regarding the creation of a duty-free zone and pledged to regulate the question of a future visa-free circulation based on bilateral agreements. The U.S. promised help and financial support for various GUUAM projects ${ }^{14}$.

The summit in Yalta (June 6-7, 2001) was of special importance for the organisation and its activity. The GUUAM Charter formulated on that occasion bestowed

11 A. Lemieszonek, GUAM-integracja ale bez udziału Rosji. Wzloty i upadki instytucjonalnej wspótpracy państw byłego ZSRR, http://www.stosunkimiedzynarodowe.pl/guam-integracja-ale-b ez-udziałurosji-wzloty-i-upadki-instytucjonalnej-współpracy-państw-byłego-zsrr (accessed on 21 II 2012); R. Mazur, GUUAM, [in:] T. Łoś-Nowak, ed., Organizacje w stosunkach międzynarodowych. Istota-mechanizmy działania-zasieg, Wrocław 2004, pp. 256-257.

12 The governments of Azerbaijan, Georgia and Turkey signed an agreement on the construction of the Baku-Tbilisi-Ceyhan pipeline shortly afterwards, p. Trzaskowski, Kulturowe źródła prozachodniej polityki zagranicznej Gruzji, in: p. Adamczewski (ed.), Konflikty na obszarze byłego ZSRR, Poznań 2009, pp. 194-195.

13 J. Siekierzyński, Historia i rola układu GUUAM we współczesnej polityce Eurazjatyckiej, in: A. Furier (ed.), Kaukaz w dobie globalizacji, Poznań 2005, p. 64.

14 A. Lemieszonek, op. cit.; A. Myśliwy, op. cit., p. 135. 
international significance on this so far regional venture. The document comprised eight articles. Article I established the following goals of the organisation: to support social and economic development; to boost trade and reinforce economic ties (including the creation of the GUUAM Free Trade Area); to develop and fully use the available transport and communication infrastructure for the organisation's benefit; to enhance regional security in all spheres of activity; to broaden scientific and cultural exchange and cooperate in humanitarian operations; to collaborate within the framework of international organisations; to fight against international terrorism, organised crime and drug trafficking; to enhance cooperation with the EU and NATO. GUUAM's main areas of cooperation are: economy, science, technology and environment, transport, energy, telecommunication infrastructure, joint investment and financial projects, culture, education, mass media, tourism, and youth exchanges. According to the Charter, GUUAM's main administrative body are the annual meetings of heads of states defining the organisation's essential areas of activity. Each member state presides for one year, in alphabetical order. The organisation's executive body is the Council of Foreign Ministers. The Council's meetings take place every six months, and their goal is to implement the provisions adopted by the member states and to put forward proposals for development and cooperation for the next presidential summit. Specialist committees comprising ministers from corresponding departments of member states were also formed. The Ministry of Foreign Affairs of Ukraine was appointed GUUAM's official press centre. Due to Moldova's refusal to sign the GUUAM Charter, the document was submitted to international coordinators for revision. In response to the Yalta events, the Russian Ministry issued a memorandum condemning the GUUAM member states for abandoning the initial spirit of their association as an informal consolidation forum, modifying its energy doctrine and imposing the idea of military cooperation ${ }^{15}$.

Detailed competencies of the Council of Foreign Ministers were defined at the second Yalta summit (July 19-20, 2002) ${ }^{16}$. The Council's tasks were expanded to feature measures of improvement of cooperation, including in diplomacy. The Council would now prepare joint statements of GUUAM member states regarding international issues and external affairs. The Committee of National Coordinators, comprising one representative from each country appointed by its Minister of Foreign Affairs, would be responsible for the organisation of the meetings of heads of states, as well as Council meetings. The Committee would gather every three months, but could consider an additional date on request of any member. Regular meetings of Ministers of Foreign Affairs, Defence, and Oil industry, as well as various experts, were envisioned. The Economic Council was established to implement trade agreements by invigorating economic cooperation, creating conditions for multilateral cooperation in transport and energy, and facilitating the integration

15 A. Lemieszonek, op. cit.; R. Mazur, op. cit., p. 257; A. Myśliwy, op. cit., pp. 135-138.

16 The representatives of five European countries, the U.S., and ten international organisations took part in the conference as observers. 
of member states with the worldwide economy. An agreement regarding their free trade area was signed. The Information Bureau was founded in Kyiv. The events of September 11, 2001 also inspired an agreement on the war on terror and organised crime. The member states asserted their determination to guarantee a political, legal and organisational foundation for action against such challenges as separatist movements, intolerance and extremism. The president of Uzbekistan did not attend the summit, as a result of the country's withdrawal from the organisation, announced one month earlier by its Ministry of Foreign Affairs. The Russian media reacted enthusiastically to this information, celebrating "the end of that virtual oddity" which they considered GUUAM to be ${ }^{17}$. The subsequent summit took place in Yalta on July 3-4, 2003. Unfortunately, most countries were largely underrepresented, as the Presidents of Azerbaijan, Uzbekistan and Moldova all declined participation, stating health problems; on the other hand, a large number of observers attended, namely 29 representatives of states and international organisations. The main accomplishment was the establishment of the GUUAM Parliamentary Assembly ${ }^{18}$. Also constituted was the Council of Presidential Representatives for the Development of Oil Transport, while GUUAM-U.S. cooperation led to the creation of the Virtual Centre for the fight against terrorism, organised crime, drug trafficking and other forms of criminal activity, as well as to the foundation of the International Centre for Analysis and Information. Another GUUAM-U.S. initiative was related to the training of antiterrorist troops to be used to guard gas pipelines and fight terrorism ${ }^{19}$.

In October 2003, GUUAM was granted observer status at the UN General Assembly. The same status was simultaneously awarded to the Eurasian Economic Union, tied to the Russian Federation.

The next GUUAM summit was supposed to take place in Batumi, on April 16, 2004. However, shortly before the meeting, the President of Moldova, Vladimir Voronin, requested a change of venue due to the unstable situation in Adjara. Islam Karimov excused himself with lack of time. The presidents being unable to reach consensus, the meeting was postponed to a further, undecided date ${ }^{20}$.

The subject of holding the postponed summit was brought up in March 2005 by V. Voronin. His efforts towards the resuscitation of GUUAM were interpreted as a pre-campaign slogan meant to assure the communist party's victory in the upcoming parliamentary election. The summit was preceded by a meeting of Vladimir

17 A. Myśliwy, op. cit., p. 136; A. Lemieszonek, op. cit.; Przemówienie Prezydenta Republiki Azerbejdżanu Hajdara Alijewa na szczycie jałtańskich przywódców państw krajów członkowskich GUUAM, 20 lipca 2002 roku, http://lib.aliyev-heritage.org/pl/3417868.html (accessed on 5 II 2012); p. Andrusieczko, Perspektywy alternatywnych organizacji regionalnych na przykładzie GUAM, in: T. Kapuśniak, ed., Wspólnota niepodległych państw: fragmentacja-bezpieczeństwo-konflikty etniczne, Lublin-Warszawa 2011, p. 46.

18 The agreement regarding the establishment of the GUUAM Parliamentary Assembly was adopted on September 24, 2004 in Kyiv. The only country not to sign the agreement was Uzbekistan. A. Myśliwy, op. cit., no. 3, p. 139.

19 Ibid., p. 136-137; A. Lemieszonek, op. cit.; Ł. Wróblewski, op. cit.

20 A. Myśliwy, op. cit., pp. 137, 139. 
Voronin, Victor Yushchenko and Micheil Saakashvili in the first days of March 2005. The Presidents of Georgia and Moldova signed a treaty called the "Map of black holes", which asserted the planned regulation of the situation in Abkhazia, Southern Ossetia, and Transnistria by requesting inter alia the withdrawal of RF troops from these territories ${ }^{21}$.

It is noteworthy that all members of GUUAM remained part of the CIS ${ }^{22}$, an entity widely perceived by analysts as an instrument of integration devised to serve the defence policies of Russia, especially in the neighbouring Caucasus and Central Asia $^{23}$. After the "Orange Revolution", the authorities in Kyiv officially admitted that the CIS, once established to alleviate the effects of the fall of the USSR, had fulfilled its purpose and that its raison dêtre, as an organisation explicitly subordinated to Russia ${ }^{24}$, was now in question. However, the change in the political situation and the events of 2008 proved otherwise. After Georgia's withdrawal from the CIS (the membership effectively ending on August 18, 2009), the Presidents of Ukraine, Azerbaijan and Moldova all participated in the CIS summit in Chisinau (October 8-9, 2009). Despite her resignation from the CIS, Georgia maintained its 75 international agreements in force with CIS members ${ }^{25}$.

In January 2005, a meeting of national coordinators took place in Chisinau, and was attended, in addition to GUUAM members, by representatives of the U.S. Department of State and of the embassies of Poland, Romania, Turkey and Bulgaria. The discussions revolved around regional cooperation. However, at the press conference closing the summit, the Foreign Minister of Moldova asserted that GUUAM's activity was not directed against Russia nor meant to be an alternative to the $\mathrm{CIS}^{26}$, serving instead to resolve internal political and economic issues, and to improve security in the region. This statement showed that GUUAM members were willing to tighten their ties with countries from outside the CIS, but not without assuring Russia of their loyalty and harmlessness.

GUUAM was also the subject of later discussions between V. Yushchenko and Georgian Prime Minister Zurab Nogaideli. The Ukrainian President suggested "filling the organisation's activity with substance"27.

The Chisinau summit (April 22, 2005) was devised as an attempt to revive the organisation, which is why it was attended by the Presidents of all member states but Uzbekistan, as well as the Presidents of Lithuania and Romania, and a rep-

21 Ibid., p. 137.

22 Ukraine did not sign the CIS Statute, therefore it is not formally a member, but only a founding state and participant.

23 M. E. Szatlach, Porozumienie regionalne w globalnym systemie bezpieczeństwa, [in:] J. Knopek, D. J. Mierzejewski, ed., Bezpieczeństwo narodowe i regionalne $w$ procesach globalizacji, Piła 2006, pp. 103-104.

24 M. Przełomiec, op. cit., p. 50.

25 M. Banaszkiewicz, Kiszyniowski szczyt WNP w odbiorze rosyjskim, "Biuletyn Międzynarodowy", vol. II (2010), pp. 207-208

26 V. Dunaeva, Razem, ale z kim?, "Nowe Państwo" 2005, no. 6, pp. 78-79.

27 A. Myśliwy, op. cit., p. 140. 
resentative of the U.S. Department of State ${ }^{28}$. According to Georgian President M. Saakashvili, a third wave of revolutions in post-Soviet republics was awaking, hence it was time to benefit from this situation by conferring a new dimension of cooperation within GUUAM. His main stipulation was to upgrade the association of a so-far casual nature with the structure of a well-functioning organisation. The heads of member states proclaimed the Declaration on stability and development, in which they asserted the aspirations of their governments to integrate with the European and Euro-Atlantic communities, their attachment to democracy and European values, and their concern regarding the threat to security caused by international terrorism and aggressive separatism. The desire to settle protracted conflicts in post-Soviet areas was defined as the new direction for cooperation ${ }^{29}$. The Ukrainian side came out with the proposal of forming an alliance that would effectively oppose the dangers of separatism. The organisation intended to seek support globally for their plans of regaining territorial integrity (i.e. Southern Ossetia and Abkhazia to be merged back with Georgia, Nagorno-Karabakh with Azerbaijan, and Transnistria with Moldova). Their close political and military cooperation was announced, including the establishment of joint peace missions under $\mathrm{UN}$ and OSCE mandates ${ }^{30}$.

During the summit, Georgia and Moldova requested the withdrawal of Russian troops from their territories. The Ukrainian President, V. Yushchenko, came forward with the idea of resolving the Transnistrian conflict ${ }^{31}$ with a seven step plan:

- the creation, by the administration of Transnistria, of conditions for the development of a civil society,

- the creation, by the administration of Transnistria, of conditions for the development of a multiparty system,

- the implementation of a democratic election to the Supreme Council (acting as parliament) in Transnistria, supervised by observers from the EU, OSCE, Ukraine, Russia and the U.S.,

- the transition of peace forces into an international mechanism and a quantitative expansion of Ukrainian peace-keeping forces,

- the inclusion of Ukrainian specialists in the monitoring of the industrial-military complex of Transnistria,

28 Although invited, the Presidents of Poland, Hungary, and Bulgaria did not attend.

29 A. Lemieszonek, op. cit.; Ł. Wróblewski, op. cit.

30 E. Wyciszkiewicz, op. cit.

31 The situation on the Transnistrian section of the border with Ukraine was tightened up after 2001 and, following a change in regulations regarding international transport in Transnistria, Moldova changed its tax and customs laws, which in turn led to an economic blockade. In response, Transnistria introduced a 20\% tax on Moldovan commodities, established special migration controls on the border along with a crossing fee. The Transnistrian government undertook several steps towards the closure of its own market for Moldovan products by introducing a 100\% tax on Moldovan products. More on this subject: N. Tsvitsinskaya, Gospodarka Naddniestrza i je powiazania z gospodarka Mołdowy, in: P. Adamczewski, ed., op. cit., pp. 157-162. 
- the creation of a monitoring group within the OSCE and other international organisations for exerting control over the transit of commodities over the Ukrainian-Transnistrian border,

- the support, by Ukraine, of the EU and U.S. in their efforts towards the resolution of the Transnistrian conflict ${ }^{32}$.

Given that the proposal had not been discussed beforehand with the Moldovan authorities, it could not be presented as a joint GUUAM stance. Nevertheless, it undoubtedly testified to Ukraine's leading role in this regional association since its beginning. The proposals presented at the GUUAM summit in Chisinau were upgraded in the so-called Yushchenko plan ${ }^{33}$, revolving around the democratisation of the Transnistrian region. The Supreme Court, appointed through a democratic election, would be approved by Chisinau as the official body to legally represent Transnistria and negotiate the division of competencies with the Moldovan authorities. The conflict would end with the signing of an agreement (together with Ukraine, Russia and the OSCE) guaranteeing Moldova's recognition of the special legal status of Transnistria. In spite of several fundamental misgivings being voiced, Yushchenko's plan was approved. It was nonetheless criticized for omitting the issue of the RF's military presence in the region. The question of withdrawing Russian troops and introducing proper supervision over the Transnistrian Moldova-Ukraine border was raised in particular by the Moldovan authorities ${ }^{34}$. However, influential economic circles in Moldova and Ukrainian were not interested in the turnout proposed by Yushchenko, as they rather saw the separatist republic as a goose laying golden eggs; and the importance of capital should not be underestimated, given its influence on the dismissal of the Ukrainian government in September $2005^{35}$. In consequence, Yushchenko's plan was implemented to a minimal degree, while Ukraine ridiculed itself and tarnished its image of a trusted partner by abandoning the international agreement on the transit of commodities over the Moldova-Ukraine border signed by the Prime Ministers of both countries, which was to enter into force on January $25,2005^{36}$. Nevertheless, strong protests were to eventually lead to the revival of the agreement on March 3, 2006. The Transnistrian and Russian authorities call the idea an "economic blockade".

The Russian Federation desired to retain its military presence in the Transnistrian region at all cost in order to hamper NATO's eastward expansion. There was no unity among the parties supposed to act as allies in the settlement of the conflict. Moldova persisted in its demand for the existing "peace mechanism" under RF supervision

32 Виктор Ющенко обсудит в Киеве свой мирньй план с президентом Приднестровья, http://www.newsru.com/world/14jul2005/smirnoff.html (accessed on 11 III 2012).

33 A supplement to the existing Kozak Plan.

34 P. Świeżak, Mołdawia/Parlament zaakceptował plan Juszczenki, http://www.psz.pl/tekst-1485/ Moldawia-Parlament-zaakceptowal-plan-Juszczenki (accessed on 13 III 2012).

35 V. Dunaeva, op. cit., p. 80.

36 M. Gołdysiak, Działalność Misji Unii Europejskiej o pomocy granicznej dla Ukrainy i Mołdawii (EU BAM) na tle naddniestrzańskiego konfliktu, "Dialogi Polityczne” 2007, no. 8, pp. 73-77. 
to be transformed into a civilian mission under international mandate-a stance supported by the U.S. - while Germany (albeit not representing the EU as a whole) passed over the presence of Russian troops in silence. A memorandum signed by Ukraine, Moldova and the European Committee on October 7, 2005 eventually led to the establishment of the civilian and advisory EU BAM border assistance mission with a view to reinforce security on the Moldovan-Ukrainian border by facilitating the proper organisation of customs and border protection outposts ${ }^{37}$.

As the question of expanding GUUAM through the admission of new members was also discussed at the Chisinau summit, rumours soon surfaced in Russia, suggesting that Poland and Romania were planning to join the organisation, which aroused associations with the historic Commonwealth of Both Nations, often referred to as "Commonwealth from sea to sea" 38 . The Russian media also reported GUUAM's criticism of Belarus, Russia's main ally, which was interpreted as the organisation's desire to inspire a "silk revolution" in Minsk in order to acquire this country as a member ${ }^{39}$. Moscow's reaction to the Chisinau summit was articulated by Mikhail Margelov, Chairman of the Foreign Affairs Committee of the Federation Council of Russia, who stated that GUUAM's only goal was to "export Orange Revolutions" The American administration officially confirmed its desire to support GUUAM in their efforts towards enforcing stability in ex-Soviet areas ${ }^{41}$.

This summit proved to be unsatisfactory and failed to provide a chance to implement the premises and goals adopted so far. This is why in August 2005, on the initiative of V. Yushchenko, a declaration was signed by himself and the Georgian President M. Saakashvili in Borjomi, Georgia, requesting GUUAM to expand its integration processes towards countries in the region of the Baltic-Black-Caspian Seas through the establishment of the Community of Democratic Choice (Ukraine, Georgia, Estonia, Lithuania, Latvia, Macedonia, Moldova, Romania and Slovenia). The UE, the U.S. and the Russian Federation were envisaged as observers ${ }^{42}$.

The next summit took place in Kyiv on May 22-23, 2006, without the participation of Uzbekistan ${ }^{43}$, hence the restoration of the former name, GUAM. The association of four states was transformed into an international body called the GUAM Organisation for Democracy and Economic Development, which then obtained a statute to be approved by the parliaments of all member states. The organisation's goal was to formalise their cooperation in improving the implementation of its

37 A. Ciupiński, Realizacja Wspólnej Polityki Bezpieczeństwa i Obrony UE na obszarze proradzieckim, in: A. Bryc, A. Legucka, A. Włodkowska-Bagan, ed., Bezpieczeństwo obszaru poradzieckiego, Warszawa 2011, pp. 136-137.

38 V. Dunaeva, op. cit., p. 79.

39 H. Głębocki, Postscriptum: gier o Eurazję ciąg dalszy, "Arcana”, 2005, no. 3, p. 144.

40 V. Dunaeva, op. cit., p. 79.

41 H. Głębocki, op. cit., p. 144.

42 E. Wyciszkiewicz, Perspektywy rozwoju organizacji GUUAM - polski punkt widzenia, "Polski Przegląd Dyplomatyczny”, vol. 5 (2006), no. 4 (26), p. 110; V. Dunaeva, op. cit., p. 79. Eventually, the following became observers: Azerbaijan, Bulgaria, the Czech Republic, Hungary, Poland and the U.S.

43 Uzbekistan officially withdrew from the organisation on May 5, 2005. 
internal policies and agreeing common strategic goals in foreign affairs. The organisation would strive to achieve energy security by means of common energy investments, pro-democratic efforts, cooperation towards the settlement of conflicts in the region with a view to guarantee security in the whole GUAM area, the rule of law, the guarantee of respect for human rights, the economic development of member states and integration with Western structures. Future plans involved the signing of an agreement on a free trade zone, and the establishment of an Energy Council. The organisation's structure comprises the Council and the Secretariat. The Council acts as the organisation's main body and operates at the level of heads of states (summit), foreign ministers, national coordinators and permanent representatives. The Council may create subsidiary and operating bodies, permanent or temporary, and organise meetings of representatives of corresponding ministries. The Secretariat of the Organisation, located in Kyiv and operating under the direction of the Secretary-General, carries out organisational and technical tasks. The decisions made by GUAM are to be decided by consensus. The organisation intends to undertake mutual cooperation with the EU, UN, U.S., Poland, the Czech Republic and Japan. During the press conference closing the summit, the participants clearly avoided antagonising Russia. Only M. Saakashvili pronounced some criticism regarding Moscow's foreign policy. The Presidents of Moldova and Ukraine preferred to focus on the positive aspects of cooperation with the RF, while the president of Azerbaijan called Azeri-Russian relations "constructive"

The following year, top-level talks took place in Baku (June 18-19, 2007). The Baku summit enjoyed the highest attendance so far, gathering representatives of 30 countries (including the U.S., Japan and China) and international organisations (OSCE, EU, NATO); the Presidents of Poland, Lithuania and Romania were present as well. Given the recent pro-Russian shift in Moldovan foreign policy, V. Voronin did not attend, while the country was represented by Prime Minister Vasile Tarle. Besides, Moldova was the only state not to ratify the Kyiv Declaration and the GUAM statute. Even though the unsettled conflicts were the prime topic of debate, the Moldovan Prime Minister avoided mentioning the Transnistrian dispute, as the issue was to be discussed during V. Voronin's meeting with Vladimir Putin planned for June 22 in Moscow. The talks in Baku focused on energy policies, including the project of extending the Odessa-Brody pipeline to Płock and creating a joint energy consortium $^{45}$. Most attention was given to the use of transit opportunities and GUAM's role as a bridge between Europe and Asia, and much space was also devoted to the issues of international terrorism, separatism and extremism, as well as international organised crime. A potential joint GUAM-Poland declaration was discussed. A meeting of the GUAM-Poland working group took place, with focus on energy coop-

44 A. Lemieszonek, op. cit.; Ł. Wróblewski, op. cit; A. Górska, GUAM-nowa organizacja międzynarodowa, http://forum.gazeta.pl/forum/w,12217,42495412,42495412,GUAM_nowa_organizacja_miedzynarodowa.html (accessed on 23 II 2012).

45 The EU, including Poland, may largely be blamed for a lack of suitable support for this project. 
eration. The scientific conference dedicated to the role of GUAM in the region and worldwide was announced to take place the following month, in hope that similar events promoting the organisation's activities would be held as often as possible ${ }^{46}$.

The heads of GUAM member states also held a meeting within the framework of the Energy Forum, which took place on October 10, 2007 in Vilnius. In addition to the Presidents of Ukraine, Georgia and Azerbaijan and the representation of Moldova, the summit was attended by the Presidents of Poland, Lithuania and Latvia, as well as the American Deputy Secretary of Energy. Stronger integration in the region, the intensification of economic exchange and the effective pursuit of dialogue between civilisations were cited as goals for further cooperation ${ }^{47}$. Azerbaijan, Georgia, Ukraine, Lithuania and Poland signed an agreement on cooperation in the energy sector; Azerbaijan, Georgia and Lithuania also became shareholders of the Sarmatia project ${ }^{48}$.

Poland is perceived by the Caucasian members of GUAM as an ideal partner in their efforts aimed at integration with the EU, hence their desire to boost existing ties. The GUAM-Poland meeting of coordinators, which took place onFebruary 21,2008 , was devoted to various forms of cooperation in trade, promotion, joint investments, energy, tourism, transport and natural environment issues; an agreement on the increase of economic turnover rates between the parties was also signed. The dialogue focused in most part on cooperation with the EU, democratisation and the adaptation of laws in different GUAM member states to European standards. The organisation invited all stakeholders to cooperate under the GUAM+ format ${ }^{49}$.

At the conference in Baku (April 15-16, 2008), dedicated to the settlement of conflicts in the territories of member states, the participants agreed that the only status of separatist republics that the central authorities may agree upon is autonomy with wide-ranging powers, while conflicts should be resolved with due regard to the territorial integrity of states ${ }^{50}$. Delegations from more than 10 countries attended the conference. According to observers, Ukraine could take over

46 W. Konończuk, Reakcje mediów rosyjskich na szczyt GUAM w Baku, http://www.osw.waw.pl/ pl/publikacje/tydzien-na-wschodzie/2007-06-20/reakcje-mediow-na-rosyjski-szczyt-GUAM-w-Baku (accessed on 19 I 2012); A. Lemieszonek, op. cit.; Szczyt GUAM w Azerbejdżanie, http://www.osw. waw.pl/pl/publikacje/tydzien-na-wschodzie/2007-06-20/szczyt-guam-w-azerbejdzanie (accessed on 19 I 2012); Комюнике Бакийского саммита ГУАМ, http://guam-organization.org/node/344 (accessed on 28 III 2012); P. Andrusieczko, op. cit., p. 50.

47 A. Lemieszonek, op. cit.

48 The Sarmatia project was established in 2007 by PERN Przyjaźń from Poland and UkrTransNafta from Ukraine. However, the project turned out to lack sufficient resources to build the Odessa-Brody-Gdańsk line back then. Sarmatia was then joined by the consortium SOCAR from Azerbaijan, GOGC from Georgia, and Klaipedos Nafta from Lithuania.

49 N. Domaniewska, Polska/Polska wspiera państwa GUAM, http://www.psz.pl/tekst-9109/ Polska-Polska-wspiera-panstwa-GUAM (accessed on 19 I 2012); Варшавское заявление СМИД ГУАМ, http://guam-organization.org/node/1215 (accessed on 28 III 2012).

50 President V. Yushchenko wished this matter would become a staple of GUAM's activity. 
mediating duties from Russia in the settlement of protracted conflicts in Georgia, Azerbaijan and Moldova ${ }^{51}$.

The next GUAM summit was held in Batumi (July 1, 2008) under the motto "GUAM: Integrating Europe's East", and saw the participation of representatives of almost 20 countries, including the Presidents of Poland and Lithuania. This summit showcased once again Moldova's lack of interest in cooperation within the Organisation, as this member state was only represented by the Minister of Internal Affairs and Deputy Minister of Foreign Affairs. A declaration was signed, affirming the desire to pursue regional cooperation and joint efforts in the struggle against modern threats, as well as the readiness to further improve the energy security system and to support the efforts to liberalise and diversify the European energy market; a resolution regarding the development of the GUAM transport corridor was also adopted. The issue of territorial integrity of member states was discussed, and a declaration on the improvement of integration efforts and security measures in the GUAM region-an integral part of the European and Eurasian zone-was signed. Potential cooperation with members of the Visehrád Group and the Baltic States was also discussed. Several bilateral sessions took place, including one on GUAM-Polish relations. Among the decisions made, one could be interpreted as a slap in the face for Russia: that was the joint declaration guaranteeing support for Ukraine in acquainting the international community with the truth about the Holodomor (the Great Famine of 1932-1933), which is widely considered to have been genocide. The Organisation also confirmed its presence at the commemoration of the 75th anniversary of these events. The commentators summed up the summit by pointing out that the declarations adopted will share the fate of their predecessors in being solely of archival value ${ }^{52}$.

M. Saakashvili and Acting President of Moldova, Mihai Ghimpu, discussed reviving GUAM on the occasion of a meeting in August 2010. The idea of inviting Belarus, in conflict with Russia at the time, to join the organisation was also taken into consideration. According to the Russian media, this was an attempt to replace Ukraine, which "had become too close to Moscow under Yanukovych and did not display any desire to continue supporting GUAM politically"53. The Georgian Ministry of Foreign Affairs informed that another GUAM summit would probably take place before the end of the year ${ }^{54}$. Unfortunately, the growing

51 A. Kowalczuk, Azerbejdżan/Konferencja GUAM na rzecz uregulowania konfliktów, http://www. psz.pl/index.php?option=com_content\&task=view\&id=10442 (accessed on 19 I 2012).

52 Szczyt GUA(M) w Gruzji, http://www.osw.waw.pl/pl/publikacje/tydzien-na-wschodzie/2008-07-09/ szczyt-guam-w-gruzji (accessed on 19 I 2012); A. Lemieszonek, op. cit.; M. Jastrzębska, Kaczyński: "Trzeba walczyć do końca", http://www.psz.pl/tekst-11775/Kaczynski-Trzeba-walczyc-do-konca (accessed on 19 I 2012); Коммюнике Батумского саммита Гуам, http://guam-organization.org/node/373 (accessed on 28 III 2012); Меморандум о взаимопонимании между Организацей, http://guam-organization.org/node/378 (accessed on 28 III 2012).

53 During the Georgian-Russian war of 2008, Victor Yanukovych advocated the independence of South Ossetia and Abkhazia.

54 Saakaszwili $i$ Ghimpu chca ożywić GUAM, http://www.wprost.pl/ar/206046/ Saakaszwili-i-Ghimpu-chca-ozywic-GUAM (accessed on 16 IV 2012). 
divergences between the goals of member states have been impeding the arrangement of another summit ever since.

In September 2008, a session of the GUAM-U.S. working group was held in New York, the organisation being represented by the Foreign Ministers of member states. The participants expressed their joint belief that international organisations should intensify their activities towards the settlement of protracted conflicts in the GUAM region with respect to the sovereignty and inviolability of state borders and international law. Measures for combating terrorism, organised crime and drug trafficking were discussed, as well as methods of assisting border guard services of member states in the provision of security to the GUAM Transport Corridor. The organisation reacted enthusiastically to the technological support offered by the U.S. ${ }^{55}$

The GUAM meeting that took place on the occasion of the OSCE summit in Astana (December 1-2, 2008) was supposed to show that, in spite of important discrepancies between declarations and reality, GUAM still attempted to implement at least some of its premises. Only in November and December 2010, ten meetings of GUAM representatives were held ${ }^{56}$. The Secretary-General also maintained an active agenda: in May 2012, he was hosted in Vienna, where he attended a meeting with students of the Diplomatic Academy, delivered a lecture on GUAM activities and the programmes in progress, and met with the Secretary-General of the $\mathrm{OSCE}^{57}$. The following month, he also met in Kyiv with the director of the Southeast European Law Enforcement Centre (SELEC), with whom he discussed the priorities of both organisations in the fight against crime and terrorism ${ }^{58}$.

Unfortunately, those initiatives turned out to be among GUAM's last important ones. The organisation's activity has since then been limited to regular meetings of working groups and national coordinators, and focused on minor, more current matters. Conferences and videoconferences, as well as information activities, mostly through the website and publications, play a major part ${ }^{59}$; they are all featured in Georgia's 2008 leadership plan, which also stipulates the creation of the GUAM Investment Bank ${ }^{60}$. Azerbaijan initiates the sessions of the working group on energy; the organisation is begining to cooperate in this field with Japan, which holds seminars for experts from member states dedicated to the topic of energy security (January 15-23, 2012). The establishment of a business forum for major com-

55 Used mostly to furnish the secretary office in Kyiv, Совместное заявлене ГУАМ-США, http:// guam-organization.org/node/512 (accessed on 28 III 2012).

56 P. Andrusieczko, op. cit., p. 51-52.

57 Рабочий визит Генеральново секретаря ГУАМ г-на В. Чечелашвили в Вену, http://guam-organization.org/node/1329 (accessed on 26 VI 2012).

58 Встреча Генерального секрегаря ГУАМ г-на В.Чечелачвили с Директором SELEC, http:// guam-organization.org/node/1335 (accessed on 1 VII 2012).

59 Detailed information on the organisation's activity can be found on its website, http://guam-organization.org/.

60 Програма председательства Грузии в Организации, http://guam-organization.org/node/377 (accessed on 28 III 2012). 
panies from the GUAM area and outside, allowing the presentation of new projects in the energy sector, has been announced ${ }^{61}$. Japan is also interested in the development of tourism in the region and supports the GUAM working group on tourism ${ }^{62}$. Azerbaijan, which took over leadership in 2012, defined its priorities as follows: joint standardisation of laws of member states, development of international economic cooperation, and the introduction of a scheme of cooperation between the parliaments of member states ${ }^{63}$. Five sessions of the GUAM Parliamentary Assembly have taken place so far. The Secretary-General of the organisation puts particular emphasis on parliamentary cooperation, with a view to further promoting the GUAM format and finalising ratification procedures on time ${ }^{64}$. The last session of the GUAM Council of National Coordinators, attended by the Foreign Minister of Azerbaijan and the Deputy Foreign Ministers of Georgia, Moldova and Ukraine, was held in Baku on May 9-10, 2012. The main issue raised was the effective implementation of projects in the fields of economy, trade, transport, energy, tourism and fighting organised crime. Measures were taken towards the implementation of current projects and the preparation of new ones within the GUAM and GUAM+ cooperation programmes ${ }^{65}$. The working group on emergencies was particularly active during this period, as its priorities included the planning of effective measures of management of large groups of people and threat prevention in the view of the Eurovision Finals in Azerbaijan and the UEFA Championship Finals in Kyiv ${ }^{66}$. An increasing importance is given to the working group on combating terrorism, organised crime and drug trafficking, the situation in neighbouring Afghanistan being a growing danger in the latter case $^{67}$. The last meeting of GUAM Foreign Ministers took place on December 7, 2012 in Dublin, on the occasion of the 19th OSCE Ministerial Council, featuring a discussion on the project of the resolution Long-term conflicts in the GUAM area and their consequences for global peace, security and development, to be subject to debate atthe UN. The idea of holding another summit in Baku in 2013 was also considered ${ }^{68}$.

61 6-е заседание Рабочей группь по енергетике, http://www.guam-organization.org/node/1295 (accessed on 28 III 2012).

62 Видеоконферениия представителей туристических администраций, http://www. guam-organization.org/node/1301 (accessed on 4 IV 2012).

63 Azerbejdzan przejąt przewodnictwo w GUAM, http://www.portal.arcana.pl/ Azerbejdzan-przejal-przewodnictwo-w-guam,2078.html (accessed on 19 VI 2012).

64 Участие Генерального секретаря в 5-м заседании Парламентской Ансамблей ГУАМ, http:// www.guam-organization.org/node/1408/ (accessed on 18 II 2013).

65 24-е Заседание Совета Национальных кординаторов ГУАМ, http://www.guam-organization. org/node/1305 (accessed on 16 IV 2012).

66 7-е заседание Рабочей группи по чрезвычайным сытуациям, http://www.guam-organization. org/node/1306 (accessed on 16 IV 2012).

67 15-е заседание Рабочей группь по борбе с терроризмом, органзованной преступностьюраспостранением наркотиков (РГБТОП) 29-30 XI 2012, http://www.guam-organization.org/node/1393 (accessed on 6 II 2013).

68 Następny szczyt GUAM odbędzie się w Azerbejdżanie, http://www.studium.uw.edu.pl/?post/15096 (accessed on 5 II 2013). 


\section{COOPERATION WITHIN G(U)UAM}

It should be noted that the participation of different countries in G(U)UAM structures was also influenced by their own paths of political and social development, hence their different levels of involvement. Ukraine and Georgia display the greatest interest and motivation. Victor Yushchenko definitely abandoned multi-vector policies and chose to favour admission to the EU and NATO as the primary goals in Ukraine's foreign relations. During Yushchenko's presidency, GUAM was considered to have made a step towards NATO and offered an opportunity to intensify relations with the $\mathrm{EU}$ (by intensifying cooperation in energy, transport and security policies for instance); it was also beneficial to the reinforcement of Ukraine's position as a regional leader ${ }^{69}$. Azerbaijan's approach is more balanced, seeking equilibrium between maintaining relations with Russia on one hand, while getting involved in GUAM and cooperating with the U.S. for economic and political reasons on the other. Russia's strong influence and economic ties also vetoed Moldova's deeper engagement in GUAM initiatives ${ }^{70}$. Little can be said about Uzbekistan's activity too; this country suspended its membership in 2002, and then signed an agreement on strategic partnership with Russia in June 2004. Uzbekistan's change of course stemmed from the growing disappointment of its authorities with mutual relations with the U.S., as well as Washington's critical stance on the country's internal situation $^{71}$. The authorities in Tashkent announced their resignation on May 5, 2005, officially citing GUUAM's departure from its initial goals in favour of an ideological and military type of cooperation as their main reason. According to the statement, the organisation has concentrated on settling protracted conflicts, forming military blocs and verifying existing systems of protection, which were all activities Uzbekistan could not participate in due to its geographic location. Tashkent also expressed concern over a potential dissemination of slogans of "victorious democracies" (Ukraine, Georgia); another explanation was Russia’s promise to support the Uzbek economy. The President of Uzbekistan did not attend the Chisinau summit, as he was supposedly afraid of the subjects that were confronted there, i.e. human rights and the mechanisms of democracy ${ }^{72}$. Islam Karimov's doubts were justified; he feared that a similar scenario to the one in Kyrgyzstan could occur, which had tried to drift politically between Russia and the U.S., only to stumble into a vio-

69 Regarding V. Yushchenko's political programme, consult: M. Figura, Europejskie aspiracje Ukrainy w pierwszych miesiącach po zwycięstwie "Pomarańczowej rewolucji", in: "Pomarańczowa rewolucja” - szansa dla ukraińskiej transformacji politycznej, ed. A. Furier, Szczecin 2006, pp. 73-82; K. Fedorowicz, „Pomarańczowa rewolucja” na Ukrainie - czas realizacji wyborczych deklaracji, in: "Pomarańczowa rewolucja" - szansa..., pp. 134-140.

70 Before the GUAM summit in Batumi, Russia lifted the very inconvenient ban on imports of Moldovan wines, which led the Moldovan President not to appear at the summit.

71 A. Lemieszonek, op. cit.

72 M. Stokłosa, Uzbekistan. Z GUUAM już tylko GUAM, http://www.psz.pl/tekst-1326/ Uzbekistan-Z-GUUAM-juz-tylko-GUAM (accessed on 19 I 2012); P. Andrusieczko, op. cit., p. 48. 
lent "Tulip Revolution"73. However, after the events in Georgia (2008), and in view of Russia's and China's rise in position supplanting the declining Western influence in the region, Uzbekistan decided once again to revive local cooperation, which resulted in Islam Karimov appearing in Baku on September 11, $2008^{74}$.

Until 2005, Georgia and Azerbaijan formed the core of the G(U)UAM pact (Ukraine's involvement was rather sporadic until Yushchenko's rise to power, the event that led the country to assume a leading role in the organisation), as they were the most interested in developing mutual relations. Given that all GUUAM countries depend on Russian energy resources, and Azerbaijan depends on Russian infrastructure for the transmission of oil and gas, it was crucial for them to conceive and build a network of pipelines to carry oil and gas from the Caucasus, Central Asia and the Caspian Sea to Europe, as well as to improve the existing communication paths, the latter being covered by the TRACECA project involving European and American participation. Several GU(U)AM summits gave special importance to discussions on the construction of the Baku-Tbilisi-Ceyhan and Baku-Supsa pipelines, the initial segments of a transit route involving maritime transport to the terminal in Odessa, and then via Gdańsk to Western Europe. The execution of such large projects depends on obtaining support from leading geopolitical powers such as the U.S. and the EU, with the ultimate goal of bypassing Russia's intermediation and achieving economic independence. GUUAM members also believed their initiative would be able to compete on the energy market with the Eurasian Economic Union dominated by Russia, a premise explicitly stressed at the 2001 Yalta summit. The Organisation sought to tighten its cooperation with Turkey, Bulgaria, and Romania, and turned to Western Europe in search of economic viability ${ }^{75}$. Energy-related investments turned out to be the most effective scenarios of regional cooperation between GUUAM members. The accomplishment of the Odessa-Brody pipeline, financed by the Ukrainian side, can be seen as another success of GUAM in the field of energy cooperation.

The most inconsistent approach adopted was that of Moldova, which spoke out several times sceptically about GU(U)AM.

The intensification of cooperation within GU(U)AM is hampered by the low level of compatibility between the economies of member states, mostly in terms of joint investments, but also in commercial exchange. The development of the latter suffers from the lack of mutual priority treatment by organisation members. According to a poll carried out among Ukrainian experts and civilians in 2001, the members of GUUAM placed sixth or eighth in the priorities for Ukraine's foreign cooperation (after the EU, U.S., the Union State of Belarus and Russia, the Council of Europe,

73 H. Głębocki, op. cit., p. 144.

74 Contacts between the two countries were limited, even within GUUAM, Prezydent Karimow w Azerbejdżanie, http://www.osw.waw.pl/pl/publikacje/tydzien-na-wschodzie/2008-09-18/prezydent-karimow-w-azerbejdzanie (accessed on 19 I 2012).

75 J. Siekierzyński, op. cit., pp. 64-65. 
NATO, the CIS and the UN) ${ }^{76}$. The members experienced trouble in decision-making regarding joint projects, which resulted in the inability to even spend the majority of the funds (around 40-50 million USD per year) offered by the American Congress ${ }^{77}$.

Economic cooperation within GU(U)AM failed to bring measurable profit. All member states face different economic issues, and the EU and Russian Federation remain their main trade partners. The GU(U)AM countries expected some support from the West. The free trade agreement could not really influence the economy of certain countries, those of Georgia and Moldova for instance, which had already saturated the Ukrainian market with their commodities. Ukraine perceives cooperation with the RF as more economically beneficial, hence the decision of joining the Common Economic Space ${ }^{78}$. The signing of the agreement on the creation of the free trade area at the 2006 Kyiv summit was interpreted by the Russian newspaper "Nezavisimaya Gazeta" as Ukraine's withdrawal from participation in the Russia-dominated Common Economic Space project ${ }^{79}$. Even though GUAM's economic potential is not large, internal trade exchange trebled over the last couple of years (in spite of the war and economic crisis) and reached 4.5 billion USD. The transport corridor is also gaining momentum. In 2009, Azeri oil covered 25\% of Ukraine's demand for oil products ${ }^{80}$. The EU definitely prefers to get involved in the construction of pipelines running from the Caspian Sea region than in the purchase of commodities produced in the South Caucasus, such as Georgian wine, the main importer of which used to be Russia ${ }^{81}$. Following Moscow's embargo on Ukrainian meat and Georgian wine, only GUAM members and Lithuania displayed economic solidarity by declaring their interest in those products ${ }^{82}$. The economic cooperation of GUAM members, focused on long-term infrastructural projects, solely depends on attracting investors from the U.S. and the EU.

\section{SECURITY ISSUES}

Military and political cooperation were also considered potentially important areas of interaction within GU(U)AM. Ever since its foundation, its member states have made declarations of activity in such organisations as the UN or the Council of Europe. There was no unanimity when it came to military cooperation, the devel-

76 S. Jasiniecki, GU(U)AM-Szansa na dywersyfikację dostaw zasobów energetycznych do Europy, "Dialogi Polityczne", no. 7, March 2007, http://www.dialogi.umk.pl/guuam-szansa-energetyka.html

(accessed on 5 II 2012).

77 E. Wyciszkiewicz, Perspektywy rozwoju organizacji GUUAM - polski punkt..., p. 104.

78 This structure was created in May 2004 and is composed of Russia, Belarus, Ukraine and Kazakhstan.

79 P. Andrusieczko, op. cit., p. 49.

80 Ibid, p. 51.

81 In 2006, Russia introduced an embargo on Georgian food products, effectively establishing an economic blockade.

82 D. Kałan, GUAM - fiasko dobrych intencji, http://www.psz.pl/tekst-33260/ Dariusz-Kalan-Guam-fiasko-dobrych-intencji (accessed 19 I 2012).. 
opment of which was a postulate of Ukraine and Georgia in the first place. However, the attempt to transform GUUAM into an organisation of a military nature, carried out at the 2001 Yalta summit, failed due to Uzbekistan's and Azerbaijan's request for the points regarding a potential intensification of military cooperation and joint peace-keeping operations to be removed from the Yalta charter ${ }^{83}$. The development of military cooperation between GU(U)AM members is blocked by the presence of Russian bases in the territories of Georgia, Azerbaijan and Moldova, which was also one of the reasons why NATO rejected GU(U)AM's proposition of cooperation. The Alliance admitted it would prefer cooperation under the Partnership for Peace programme with each GUAM member separately (which boils down to trade and modernisation of military equipment, as well as training and participation in NATO practice manoeuvres $)^{84}$. However, cooperation in military and political spheres has proved difficult when the majority of its members maintain a policy of equilibrium between Russia and the West; Azeri President Ilham Aliyev went even further when he stated during Vladimir Putin's visit (February 21-22, 2006) that "the relations between Russia and Azerbaijan should be seen as a strategic partnership" 85 . Georgia's Security Strategy underlines the country's aspirations of achieving full integration with NATO and its efforts towards improving the level of security in the Black Sea region as an element of the Euro-Atlantic Security System ${ }^{86}$. NATO has elaborated an Individual partnership activity plan for Georgia. After the adoption of the "Train and Equip" programme, which enabled the American government to finance and improve the Georgian army, the U.S. became Georgia's main partner in questions of security ${ }^{87}$. From the economic point of view, Georgia's aspirations to NATO membership improve this country's image and safety in the eyes of foreign investors ${ }^{88}$. However, the Alliance lost on credibility in the eyes of the Georgian authorities during the war against Russia in 2008, and mutual relations following the "Five Days War" started to normalise only in $2011^{89}$. In Azerbaijan, there is not and never was unanimity in opinions regarding accession to NATO. Several Azeri politicians have repeatedly declared their enthusiasm towards joining the Alliance, but such a position was never confirmed by the President. Nevertheless, Azerbaijan is intensifying its cooperation with NATO, in spite of internal opposition ${ }^{90}$. NATO

83 S. Jasiniecki, op. cit.; P. Andrusieczko, op. cit., p. 45.

84 Ibid.

85 As quoted by J. Brodowski, op. cit., p. 98.

86 A. Igharkava, Rola NATO w gruzińskiej strategii bezpieczeństwa narodowego, in: W. Baluk, ed., Polityka zagraniczna i bezpieczeństwa krajów Wspólnoty Niepodległych Państw, Wrocław 2008, p. 201,

87 Georgia supports American foreign policy, and sent one of the largest missions to Iraq-850 soldiers (second biggest among non-NATO members)—-with no specified ending date. J. Stańczyk, Gruzja, in: J. M. Fiszer, ed., Systemy polityczne oraz polityka wewnętrzna i zagraniczna w państwach postkomunistycznych Europy i Azji w latach 2004-2005, Warsaw 2005, p. 147.

88 A. Igharkava, op. cit., p. 207.

89 P. A. Maciążek, Gruzja w NATO? Rasmussen potwierdza, http://politykawschodnia.pl/index. php/2012/04/12/maciazek-gruzja-w-nato-rasmussen-potwierdza.html (accessed on 17 IV 2012).

90 A. Orzelska, Azerbejdżan, in: J. M. Fiszer (ed.), op. cit., p. 141. 
's interest in Azerbaijan increased recently in view of a possible U.S. attack on Iran. A potential war between the West and Iran, along with Azerbaijan's accession to NATO, offers Baku the prospect of building a "Greater Azerbaijan" at Iran's expense ${ }^{91}$. According to the head of the Russian Military Forecasting Centre, colonel Anatoliy Tsyganok, "there is a possibility, in the case of a war against Iran, of the post-Soviet republics in the Southern Caucasus being drawn into the conflict"92. The only question remaining is: where would the hypothetical Russian intervention take place... Georgia? Azerbaijan?

After the events of September 11, 2001, the GUUAM member states joined the coalition against terrorism. Uzbekistan eventually became the main beneficiary of funds devoted to that purpose due to its location in the heart of Central Asia (which makes it vulnerable to aggression from all sides) and the fact that it maintains the only efficient army in the region. Uzbekistan also gained favour by granting the U.S. Army access to its bases without asking Moscow for permis$\operatorname{sion}^{93}$. Unfortunately, a major part of the funds obtained was embezzled or used for other purposes. Until 2003, the Uzbek authorities cooperated with the U.S. in the training of their officers, which spared them American interventions in the breaking of human rights by Islam Karimov's regime ${ }^{94}$. American diplomacy also motivated Turkey to strengthen contacts in the region, with Azerbaijan and Georgia among others ${ }^{95}$.

Even though Ukraine belongs to the pro-Western side of GU(U)AM in terms of development of military cooperation, security remains an issue in which this country has never freed itself from Russia's influence. When the Tashkent Pact was reorganised in 2002 and the Collective Security Treaty Organization (CSTO) was thus born, Ukraine officially proclaimed its desire to join NATO in the future ${ }^{96}$. Ukraine remains nonetheless an observer during the main CSTO sessions, being a signatory of an internal CIS agreement on the use of post-Soviet warning systems against air and rocket attacks, still partly in use in Ukraine. Kyiv is also bound by an agreement

91 The Azeri minority makes up to $24 \%$ of the Iranian population. p. Woźniak, Idea "Wielkiego Azerbejdżanu”, http://politykawschodnia.pl/index.php/2012/02/15/wozniak-idea-wielkiego-azerbejdzanu.html (accessed on 19 IV 2012).

92 As quoted by P. A. Maciążek, Kreml potrzebuje wojny na Kaukazie, http://politykawschodnia. pl/index.php/2012/01/20/maciazek-kreml-potrzebuje-wojny-na-Kaukazie (accessed on 21 III 2012). Colonel Tsyganok also published a book on the 2008 war in 2012; consult А. Цыганок, Война на Кавказе 2008: Русский взгляд.

93 More on this subject: M. A. Piotrowski, Azja Środkowa po 11 września, "Sprawy Międzynarodowe", 2002, no. 1, pp. 155-157; Z. Lewicki, Ewolucja polityki USA wobec Azji po 11 września, "Sprawy Międzynarodowe" 2002, no. 1, p. 63.

94 H. Głębocki, Gry w islam. Radykalizm islamski w polityce Rosji na Kaukazie, in: idem, Kresy Imperium. Szkice i materialy do dziejów polityki Rosji wobec jej peryferii (XVIII-XXI wiek), Kraków 2006, pp. 538-540; J. Siekierzyński, op.cit., p. 66.

95 J. Siekierzyński, op. cit., p. 66; A. Myśliwy, op. cit., p. 136.

96 T. Kapuśniak, Y. Tymkiv, Polityka zagraniczna i bezpieczeństwa Ukrainy w czasie prezydentury Wiktora Juszczenki, Prace Instytutu Europy Środkowo-Wschodniej, Lublin-Lviv 2009, pp. 18-19. 
with Moscow on aeronautical information ${ }^{97}$. Ukraine's security policies lack a reasonable and consistent strategy when it comes to the Russian Federation. Both countries pursue military and technological cooperation ${ }^{98}$. At a sub-regional level within the CIS, Ukraine and Russia cooperate in the framework of the CIS Antiterrorist Centre, operating since June 2000, as well as the Office for the Coordination of the Fight against Organised Crime ${ }^{99}$. The functioning of a general security system within the CIS became a drag factor for the states seeking integration with NATO. Ukraine desires to act as the nexus tying the security systems of the East and the West. In 2005, after the "Orange revolution", V. Yushchenko declared NATO membership as the ultimate goal of Ukraine's cooperation with the Alliance ${ }^{100}$.

GUUAM also planned the formation of a joint military unit to protect the Baku-Supsa pipeline. Yet, in spite of the joint manoeuvres of Ukrainian, Georgian and Azeri troops that took place in 2001 in Georgia, no such unit was finally created ${ }^{101}$.

At the Chisinau summit, Georgia and Ukraine proposed the creation of $\mathrm{GU}(\mathrm{U})$ AM troops under UN or OSCE auspices to operate in regions of conflict ${ }^{102}$. This was to be the best solution for those countries. The meeting of representatives of the Ministries of Defence and General Staffs of GUAM members, which took place in August 2006 in Tbilisi, marked the beginning of talks on the establishment of a joint peace-keeping force battalion. According to the Georgian Ministry of Defence, the unit could participate in peace and humanitarian missions under UN, OSCE, NATO, and EU command. Legal solutions regulating the functioning of GUAM peace-keeping forces and other military cooperation issues were debated. According to the Russian press, the Moldovan representatives backed out from the talks in Tbilisi, motivating their decision with an excerpt from their constitution affirming the neutral status of their country and a ban on joining military blocs ${ }^{103}$. The Baku summit in June 2007 was devoted inter alia to the project of creating a GUAM peace battalion that could be deployed in conflict areas in GUAM members' territories ${ }^{104}$. The idea of an internal peace-keeping force was criticised by V. Voronin ${ }^{105}$. The expulsion of Russian forces and the possibility of creating a separate security system were among the organisation's main goals. However, the repeated declarations of solidarity and desire to guarantee security in the region turned out to be empty words in face of the Russian-Georgian war. Only Ukraine opted clearly for Georgia, but this could hardly be considered an official GUAM

97 Ibid, p. 20.

98 Ibid, p. 21.

$99 \mathrm{Ibid}$, p. 21-22.

$100 \mathrm{Ibid}, \mathrm{p} .25$.

101 J. Darski, GUUAM, http://darski.niezalezna.pl/node/1719 (accessed on 19 I 2012).

102 H. Głębocki, Postscriptum: gier o Eurazję..., p. 144

103 P. Świeżak, Gruzja/GUAM rozmawia o wspólnych siłach zbrojnych, http://www.psz.pl/index. php?option=content\&task=view\&id=3148 (accessed on 26 III 2012).

104 W. Konończuk, op. cit.

105 GUAM/Prezydenci Polski i Litwy przybęda na szczyt, http://www.psz.pl/index.php?option=com content\&task=view\&id=11720 (accessed on 19 I 2012). 
stance. The abstention of Azeri and Moldovan leaders confirmed that the interests of GUAM members were irreconcilable in the longer term ${ }^{106}$. Following the experience of 2008, which taught the member states that they could not rely, in terms of security, on external support, i.e. Western countries and the U.S., the development of regional security structures by means of local multilateral agreements, though still within the framework of a global security system, appears to be the most beneficial solution for this organisation. This option, however, probably remains impossible to implement.

\section{OIL, GAS AND POLITICS}

Our considerations would best be illustrated with the words of American publicist Thomas L. Friedman: "the higher the price goes, the less petrolist leaders are sensitive to what the world thinks or says about them"107.

In the military sphere, a lack of energy independence is considered one of the main threats to a country's security. Meanwhile, the existing infrastructure of the fuel-energy complex inherited from the USSR limits considerably the possibility of importing gas from outside post-Soviet territories ${ }^{108}$.

Ukraine is basically dependent on importing energy resources from Russia, or from Central Asia through Russia. The RF, on the other hand, depends on the transit of these resources across Ukrainian territory; around 45\% of Russian oil exported to Western countries flows through Ukraine. Russia also managed to take over several Ukrainian petrol complexes and now controls four out of six major Ukrainian refineries: Kherson, Lysychansk, Odessa and Kremenchuk. V. Yushchenko's main foreign policy planks included the creation in post-Soviet territories of political and energy alliances independent of Russia; for instance, Ukraine was involved in a joint project, together with Poland, Azerbaijan, Georgia and Lithuania, of creating a new transmission corridor for oil, straight from the Caspian Sea region to its European recipients. The Eurasian Oil Transport Corridor project was discussed during V. Yushchenko's presidency at four energy summits ${ }^{109}$. The projected Odessa-Brody-Płock pipeline was to be Ukraine's step towards liberating itself from dependence on Russian oil, permitting Ukraine and Poland to import oil from the Caspian Sea basin. In the end, Russia managed to reverse the flow direction of the Odessa-Brody pipeline so

106 Foreign analysts also wonder whether GUAM has any future after the August 2008 war, consult. P. Goble, GUAM After Georgia: More Important than Ever or Soon to Die?, http://azer.com/ aiweb/categories/caucasus_crisis/index/cc_articles/goble/goble_2008/goble_special/goble_guam. html (accessed on 22 II 2012).

107 E. Wyciszkiewicz, Rosyjski sektor naftowo-gazowy - uwarunkowania wewnętrzne i perspektywy rozwoju, in: E. Wyciszkiewicz, ed., Geopolityka rurociagów. Wspótzależność energetyczna a stosunki międzypaństwowe na obszarze postsowieckim, Warsaw 2008, p. 40.

108 A. Szeptycki, Stosunki między Federacją Rosyjską a Ukrainq w sektorze gazowym, in: E. Wyciszkiewicz, ed., Geopolityka rurociagów..., pp. 101-102.

109 Rusza szczyt energetyczny w Baku, http://www.money.pl/gospodarka/wiadomosci/artykuł/ rusza;szczyt;energetyczny;w;baku;166,0,384934.html (accessed on 18 II 2012). 
that it could be used to import oil by Ukraine from Russia ${ }^{110}$. Until 2001, Russia was also the largest exporter of gas to Ukraine. Turkmenistan then took over, but the imported gas still flows through Russian territory, hence both the quotas and the prices at the border depend on agreements between Ukraine and Russia. Turkmenistan is also an unreliable partner due to the unpredictability of its regime.

Russia seeks to gain control over the Ukrainian gas complex or to find an alternative solution that would allow it to export gas to European recipients without passing through Ukraine (accused of stealing gas exported westwards). Ukraine does not have the possibility to render itself independent from Russian gas supplies due to this country's position in the gas sector in Central Asia (Turkmenistan, Uzbekistan, Kazakhstan are becoming increasingly dependent on Russia), as well as Russia's geographic location imposing its transit services ${ }^{111}$.

Georgia too depends on Russian supplies. The RF's gas policy towards Georgia was meant to maintain its dependence on cheap resources and to take over energy assets and infrastructure. The Georgian electricity sector fell under control of Russian monopolists RAO UES, who took over shares in numerous distribution companies and power plants ${ }^{112}$. After Gazprom managed to enter the Georgian market in 2003 (the Georgian interest group supported the expansion of Russian capital, counting on profits), Russia's primary goal became the takeover of the main gas lines, in order to gain control over the North-South axis, obtain a new opportunity for cooperation with Iran and hamper the implementation of the Baku-Tbilisi-Erzurum project. Therefore, in order to minimise dependence on Russia, the BTF gas supply contracts must be changed in a way that Azerbaijan would become the dominant supplier. According to the agreements, Turkey would be the supplies' main recipient, while Azerbaijan and Georgia would receive smaller quantities of gas for their transit services ${ }^{113}$. Both Azerbaijan and Georgia are striving to become independent of Russian supplies as soon as possible. In crisis situations, when they cannot reach compromise regarding the prices of gas imported from Russia, or when the supplies are halted by Russia due, for instance, to attacks on the pipeline in Southern Russia, they switch momentarilt to Iranian supplies ${ }^{114}$.

Moldova shares the same issue of dependence on Russia, and is also crucial to Russia in conveying resources to the Balkan markets. Russia managed to dominate the transport network in Moldova and controls the entire gas and electricity sector $^{115}$. As a result of Moldova's and Transnistria's dependence on Russian supplies,

110 A. Szeptycki, op. cit., p. 100.

111 Ibid, pp. 121-123.

112 E. Wyciszkiewicz, Rosyjska polityka energetyczna $w$ basenie Morza Kaspijskiego, in: E. Wyciszkiewicz, ed., Geopolityka rurociąów..., p. 179.

113 Ibid, pp. 179-181.

114 Ibid, pp. 179-181.

115 P. Wróbel, Wplyw Rosji na współczesne bezpieczeństwo energetyczne Unii Europejskiej, in: J. M. Fiszer, ed., Polska w Unii Europejskiej. Aspekty polityczne, międzynarodowe, społeczno-gospodarcze i wojskowe, Warsaw 2009, pp. 314-315. 
as well as the dominance of Russian capital in several strategic local companies and the presence of RF troops in the region, Russia exerts political pressure and effectively disturbs the settlement of the Transnistrian conflict (all the while officially declaring support and involvement in its resolution). During the visit of Aleksey Ostrovsky, Chairman of the State Duma Committee for the CIS and Russian Diaspora Relations, the authorities in Chisinau were informed that Russia expects Moldova to opt out of GUAM, which Moscow considers an anti-Russian organisation ${ }^{116}$. By raising prices and maintaining a strict approach regarding the settlement of payments for the gas already delivered (in the case of Ukraine and Moldova), Russia appears to hold all the cards ${ }^{117}$. The European recipients of Russian gas often suffer the consequences of this situation. The one solution to this issue is the achievement of complete independence from Russian resources by all GUAM members. Diversification should embrace both resources and transport routes, and lies within the interest of all mentioned countries, as well as the EU and U.S., but does GUAM actually have any palpable clout? Would exploiting the issue of energy security ever attract strong international support for the organisation?

The European states and the U.S. focus on the achievement of economic goals, reinforcing as a consequence their political position in the Eurasian area. But for the Transcaucasian states, this process constitutes an important opportunity to obtain the support necessary to accomplish their basic politic aspirations. The launch of new infrastructure for oil (Baku-Tbilisi-Ceyhan ${ }^{118}$ ) and gas (Baku-Tbilisi-Erzurum) pipeline involved the whole region in a network of strategic political and economic ties with western markets, yet it still failed to provide an impulse large enough to trigger economic development. At the Kyiv Energy Security summit (May 23, 2008), where the Odessa-Brody oil pipeline with its extension to Europe was discussed, the representatives of Azerbaijan refused to answer the question whether their country would be able to secure a sufficient amount of oil for the project. The Azeri experts pointed out that long-term contracts oblige Azerbaijan to supply too much oil for the country to gather its own surplus resources ${ }^{119}$. All GU(U)AM members were interested in oil transport routes; but it could serve as a unifying factor as much as a dividing one. In 2002, the Moldovan President V. Voronin declared that his country would now prioritise its own interests, lobbying for gas and oil from the Caspian region to flow to Europe through Moldova, and thus opposing

116 Nowe elementy $w$ rosyjskim stanowisku wobec konfliktu $w$ Naddniestrzu, an opinion of OSW, http://www.osw.waw.pl/pl/publikacje/tydzien-na-wschodzie/2008-06-04/nowe-elementy-w-rosyjskim-stanowisku-wobec-konfliktu-w-nadniestrzu (accessed on 19 I 2012).

117 The Russian resource policy towards CIS members is also extensively reviewed by M. Olesińka, Egzemplifikacja politycznych uwarunkowań strategii marketingowe koncernu energetycznego Gazprom w relacjach $z$ krajami WNP, http://szczesniak.pl/files/olesinska_gazprom_polityka_strategia_marketingowa_WNP.pdf (accessed on 20 III 2012).

118 The opening ceremony on May 25, 2005, was attended by the Presidents of Azerbaijan, Georgia and Turkey, as well as the U.S. Minister of Energy.

119 Azerbaijan's decisions in this matter will depend on precise economic and political benefits, P. Andrusieczko, op. cit., p. 49. 
a more reliable Ukrainian route. Faithful to this strategy, he announced he would not participate in the next summit that was to take place in Yalta in $2003^{120}$.

All GU(U)AM member states took part in the TRACECA project co-financed by the European Union, but unfortunately, this initiative did not lead to the creation of supranational structures. The largest investments, such as the Baku-Tbilisi-Ceyhan oil pipeline and the Baku-Tbilisi-Erzurum gas pipeline, were followed by the construction of a transregional railroad from Kars to Baku via Tbilisi, which stimulated cooperation between Turkey, Georgia and Azerbaijan ${ }^{121}$. The Baku-Tbilisi-Kars railroad is intended to open the shortest corridor possible to Central Asia, as an alternative to the route via Iran ${ }^{122}$. According to the Russian press agency "RosBalt", the route should be ready for exploitation in $2013^{123}$. Other projects related to rail freight are included in the European Neighbourhood Policy (ENP) and are supported by all four members of GUAM. The EU also co-financed the INOGATE (Intrastate Oil Gas Transport to Europe) project. The European Union is admittedly interested in launching new investments in the Caspian Sea region and supports the construction of gas pipelines to transfer resources to Europe and China, but the large amount of countries that agreements have to be signed with, the complexity of financing and uncertainty of future demand, all render the desired goals unattainable. The construction plan for the gas pipeline "Nabucco", still not implemented, may serve here as an example. In line with the decisions made in January 2011 under strong Turkish pressure, the pipeline was shortened (it was supposed to run from Azerbaijan to Austria via Turkey, Bulgaria, Romania and Hungary) and is supposed to transmit only half of the 31 billion $\mathrm{m}^{3}$ per year originally planned ${ }^{124}$.

Russia eventually saw its chance in the prolonged negotiations regarding the launch of the construction works. In October 2009, the Russian company Gazprom and the Azeri SOCAR signed a contract on the supply of natural gas from Azerbaijan to Russia, which began on January $1,2010^{125}$. The initial quota was 500 million $\mathrm{m}^{3}$ per year, but it may rise, as the Russian side has declared the desire to purchase up to 1.5 billion $\mathrm{m}^{3}$ of Azeri gas per year in the future. The Kazi-Magomed-Mozdok pipeline was modified and the resource flow was reversed for the agreement to be realised, and cooperation between Russia and Azerbaijan in the gas sector was

120 V. Dunaeva, op. cit., p. 78.

121 P. Adamczewski, Geopolityczne znaczenie Azerbejdżanu, in: J. Marszałek-Kawa, ed., Strategie w polityce azjatyckiej. Rozważania o możliwościach wspótczesnej Azji, Toruń 2011, p. 138.

122 L. Papuashvili, Geopolityczne położenie Gruzji a rozwój ekonomiczny kraju, in: J. Marszałek-Kawa, ed., Wartości azjatyckie, polityka i prawa człowieka, Toruń 2010, p. 309.

123 Gruzja Omijajac Rosję, http://www.kresy.pl/publicystyka,analizy?zobacz/gruzja-omijajac-rosje (accessed on 26 VI 2012).

124 Gazociąg Nabucco będzie tańszy i krótszy, http://forsal.pl/artykuly/597900,gazociag_nabucco_ bedzie_krotszy_i_tanszy.html (accessed on 10 III 2012).

125 Allegedly, the decision was also motivated by an improvement in Turkish-Armenian relations (contract from October 10, 2009). In order to avoid being left alone before the ultimate settlement of the Nagorno-Karabakh conflict, Azerbaijan attempts to strengthen its ties with Russia, Armenia's main ally. 
thus revived ${ }^{126}$. By signing the agreement, the authorities in Baku expressed their increasing impatience caused by the lack of conclusive decisions from the EU regarding the realisation of the "Nabucco" pipeline. In view of the impossibility of achieving agreement, some of the companies, such as the German RWE, are considering withdrawing from the "Nabucco" consortium. The one question that remains: will it even get finished? ${ }^{127}$ The Azeri side has already warned Brussels several times, threating the EU with the contemplated plan of redirecting their resources towards Asian recipients, such as China. Russia is not standing by idly either, implementing instead its own construction plan for the South Stream pipeline, a competitor for "Nabucco", given that it should deliver gas to the very same recipients. Russia also offered Turkey shares in its project in order to draw it away from "Nabucco"128. The pipeline, which Gazprom intends to lay down in cooperation with the Italian company Eni, should be ready for exploitation by 2015 and transmit 63 billion $\mathrm{m}^{3}$ per year ${ }^{129}$. In this view, the Caspian region has an even lesser chance of seeing the White Stream pipeline (Georgia-Ukraine-EU) completed, through which gas was supposed to flow to the EU from Azerbaijan, and later also Turkmenistan and Kazakhstan ${ }^{130}$. Russia is sustaining its unrelenting lobbying in Georgia and Ukraine, seeking to convince the authorities of those states as to the groundlessness of getting involved in the White Stream project ${ }^{131}$.

Ukraine's role as a transit country is problematic ${ }^{132}$. The gas crisis of 2006, the suspicions that Ukraine may be intercepting a part of the deliveries addressed to the EU, as well as the change in its political situation and public opinion all render this country a decreasingly credible partner. The signing of a contract by Presidents Yanukovych and Medvedev on April 21, 2010 in Kharkov was interpreted as the announcement of a new phase in the relations between Ukraine and Russia. For the price of allowing the Black Sea Fleet to station in Crimea until 2042, Ukraine obtained cheaper gas from Russia (a 100 USD discount deducted from the price of 330 USD for 1.000 $\mathrm{m}^{3}$ of gas until 2019) ${ }^{133}$. In mid-May 2012, the Ukrainian Prime Minister Mykola

126 P. Adamczewski, op. cit., pp. 133-134.

127 RWE może porzucić budowe gazociagu Nabucco, http://wyborcza.biz/ biznes/1,100896,10986209,RWE_moze_porzucic_budowe_gazociagu_Nabucco_html (accessed on 10 III 2012).

128 P. Adamczewski, op. cit., pp. 135-136.

129 E. Kustra, Zakaukazie a dywersyfikacja dostaw surowców przez UE i USA, http:// www.psz.pl/ Zakaukazie-a-dywersyfikacja-dostaw-surowcow-przez-UE-i-USA (accessed on 10 III 2012).

130 More on these investments in the Caspian Sea region: D. Niedziółka, Bezpieczeństwo energetyczne na obszarze poradzieckim, in: A. Bryc, A. Legucka, A. Włodkowska-Bagan (ed.), op. cit., pp. 291-292.

131 Ibid, p. 292.

132 Russia circumvented all transit countries by opening its first line of the Nord Stream pipeline (from Russia to Germany under the Baltic Sea) on November 8, 2011.

133 Prior to the signing of the agreement, the Ukrainian media reported about on-going negotiations regarding the lowering of prices of Russian gas in exchange for Russia's right to $80 \%$ of the vast gas deposits along the Ukrainian border. This way, Russia would secure a continuous gas supply route to Western Europe until the construction of alternative gas corridors, independently from gas 
Azarov admitted that, in reality, the "Kharkov agreement" failed to bring Ukraine any cheaper gas and that the Ukrainian government was requesting Russia's adherence to the terms of contract in vain ${ }^{134}$. Energy issues are starting to play a leading role in Ukrainian politics, leading to a revaluation of policies by Yanukovych's camp. In response to the South Stream project, Yanukovych rejected the Customs Union proposal and related discount prices on resources, deciding instead to build a gas port near Odessa and reduce Ukraine's obligations arising from binding contracts for Russian gas supplies. Ukraine is interested in plugging into the Trans-Anatolian Pipeline and participating in the Azeri-Georgian-Romanian interconnector, which would allow transporting liquid gas from the Caspian Sea to Europe ${ }^{135}$. Ukraine is seeking to strengthen its ties with Azerbaijan, thus stressing anew its presence in GUAM. But there is also another completely different matter of great importance remaining, which concerns every state involved in those projects: guaranteeing protection for all the pipelines. The lesson given by Russia during the 2008 war against Georgia proved that security ought to be an important issue to Caucasian states. Even after President Medvedev announced the "cessation of military operations", Russian troops still occupied Gori (crossed by the Baku-Supsa pipeline) and Poti. They also destroyed the Georgian oil terminal in Poti, as well as rolling stock and railroad infrastructure along with bridges used to transport oil from other regions of Georgia ${ }^{136}$. The project of creating an international control centre for the quality and quantity of Russian gas sent through Ukraine to the EU, proposed at the GUAM summit in Batumi, was reported by the Russian "Nezavisimaja Gazeta" in the following words: "GUAM wants to become the depository (of gas ${ }^{137}$ ) for the EU". Russia is still perceived as an oil giant, causing Western policies towards the Federation to lack uniformity, while the contract signed on April 16, 2012, between Exxon Mobil, the leader on the American oil market, and Russian top player Rosneft, regarding the joint exploitation of oil and gas deposits from the bottom of the Black Sea and the Kara Sea in the Arctic, is definitely bad news for European-Caucasian-Asian investments ${ }^{138}$. Back in 2008, the Georgian expert Giorgi Khukhashvili wrote that

relations with Ukraine. P. Andrusieczko, Flota za gaz, http://www.new.org.pl/2010-05-01,flota_za_gaz. html (accessed on 22 VI 2012).

134 Porozumienie charkowskie może zostać unieważnione, http://www.studium.uw.edu. $\mathrm{pl} /$ ?post/13360 (accessed on 22 VI 2012).

135 P. A. Maciążek, Powinniśmy kibicować zwycięstwu niebieskich, http://politykawschodnia.pl/ index.php/2012/10/28/maciozek-powinnismy-kibicowac-zwyciestwu-niebieskich-wybory-na-ukrainie (accessed on 6 II 2013).

136 P. Wipler, Rosyjska lekcja geopolityki, "Obserwator. Biuletyn Biura Bezpieczeństwa Narodowego", p. 22-23, http://www.bbn.gov.pl/palm/pl/501/1497/OBSERWATOT.BBN.html (accessed on 10 III 2012).

137 "Nezavisimaya Gazeta" - GUAM chce zostać unijna dyspozytornia gazu, http://wiadomosci. gazeta.pl/wiadomosci/1,114873,5414028.html (accessed on 17 IV 2012).

138 This contract is of great historic importance, as for the first time in history the Russian State Oil Company would be allowed to exploit deposits in North America. Washington had already refused such a right before (to the Chinese for instance). A. Kublik, Łupki za Arktykę, "Gazeta Wyborcza", 18 IV 2012, p. 1. 
the GUAM members' desire to participate in the process of strengthening the energy security of Europe is understandable, but "all the cards are in Russia's hand". Therefore the creation of an adequate counterweight by GUAM with its minimal resources is virtually impossible ${ }^{139}$.

EU contacts with the transit states for energy resources are maintained mostly under the auspices of the European Neighbour Policies programme, whereby political, security, economic, trade and energy cooperation issues are all rolled into one. The programme is aimed at developing cooperation in accordance with EU standards and supporting democracy and free market reforms. It offers financial and technical support in implementing goals defined in bilateral agreements with different countries under the ENP. All GUAM members are covered by the ENP ${ }^{140}$, even though at first the EU was only interested in Ukraine and Moldova, and it's only at the beginning of the 21 st century that the EU showed interest in Transcaucasian countries due to their geopolitical and geo-economic position (since June 2004, the ENP covers Azerbaijan, Georgia and Armenia, the latter not being a part of GUAM ${ }^{141}$. The EU seemed not to mind that Azerbaijan was repeatedly criticised for its questionable record regarding human rights ${ }^{142}$. November 2006 saw the adoption of the so-called Operating Plans for cooperation between the EU and each GUAM country separately for the upcoming 5 years, covering the areas of: democracy, human rights, law enforcement, economic reforms, overcoming poverty, reforming customs and tax laws, regional cooperation, international cooperation in energy, security, joint activities in the settlement of armed conflicts ${ }^{143}$. According to experts, the ENP is showing decreasing effectiveness. For GUUAM members, the failure in the extension of the security pact on neighbouring countries seemed to be of paramount importance, and reality proved that the EU did not have sufficient resources and possibilities and resolve to broker settlement in Eastern Europe ${ }^{144}$. In this view, the Eastern Partnership, initiated by Poland, was supposed to be a more reliable version of the ENP. Indeed, Poland would benefit from closer cooperation between the EU and Eastern states, as they shared points of mutual interest in economic and energy matters (the extension of the Odessa-Brody pipeline to Płock, the Caspian-Black Sea gas corridor) and security (the so-called Eastern Dimension

139 "Nezavisimaya Gazeta" - GUAM chce zostać unijna dyspozytornia gazu...

140 More on this subject: A. Staszczyk, ed., Europa Wschodnia i Kaukaz Poludniowy w polityce Unii Europejskiej, Szczecin 2011.

141 K. Strachota, Kraje Południowego Kaukazu (Armenia, Azerbejdżan, Gruzja), in: J. M. Fiszer, ed., Sytuacja wewnętrzna w krajach postkomunistycznych Europy i Azji oraz ich polityka międzynarodowa w latach 2006-2007, Warsaw 2007, p. 88.

142 A. Orzelska, op. cit., p. 140.

143 K. Strachota, op. cit., pp. 88-89.

144 Ukrainian experts believed that the lack of suitable support for GUAM from Brussels was due to Russian-EU relations and the latter's dependence on Russian gas and oil supplies, while in the EU, the dominant point of view was that the GUAM project had been initiated by the U.S. and remained unde ofr the strong influence of Washington. P. Andrusieczko, Perspektywy alternatywnych organizacji..., p. 47. 
of the North-Atlantic Pact $)^{145}$. Poland relates to the idea of solidarity within the EU in terms of natural gas and oil, which would be enforced through international energy policies actively supporting European interests. The international contracts signed with Russia should include the eventuality of a mutual liberalisation of conditions in trade, investments in research and extraction markets, retail trade and distribution, as well as cover the question of access to pipelines in states lying along the transit and transmission corridors ${ }^{146}$. But how much support can the EU really offer to GUAM members covered by the ENP and Eastern Partnership? It is possible to suspect that the EU decided to include Azerbaijan and Georgia in the ENP for the sake of its own profit, as newly accepted countries are usually subject to pressure regarding democratisation, respect of human rights and the rule of law, though Azerbaijan is far from embracing these ideas and does not seem to care. The dominating position of the EU over the countries covered by the ENP was obvious from the beginning. The formula of accession negotiations was blatantly one-sided, forcing the candidate country to fulfil a series of conditions in order to get approved ${ }^{147}$. Also, the position of countries within the Eastern Partnership is far weaker in relations with the EU than Russia's. The Eastern Partnership idea changed little in the EU's policies towards the countries under its influence. Some analysts argue nowadays whether the EU policies towards countries covered by the ENP represent the EU's desire to regulate relations with their external neighbours, or the end of the European integration process ${ }^{148}$. If the European Union has neither the possibility nor the desire to resolve the problems of countries covered by the ENP, it will care even less about doing so by supporting GUAM. Since its inception, the organisation could only count on oral declarations and financial support from the EU as as from the U.S. The events of 2008, which showed that no one intends to die for Georgia (the West abstained even from imposing economic sanctions on Russia ${ }^{149}$ ), were proof that the future may offer little change in this matter.

\section{WHAT NOW?}

GUAM's history proves that Janusz Korwin-Mikke, the Polish libertarian politician, was right when he stated in 2006 that "GUAM would rather remain a declaration of intent than become an actual bloc"150. The statehoods of GUAM members are

145 Poland is actively advocating a larger diversification in the ENP policies not only in terms of individual relations with different countries, but also at regional level, in: J. Diec, ed., Rozpad ZSRR i jego konsekwencje dla Europy i świata, część III Kontekst międzynarodowy, Kraków 2011, p. 304.

146 C. T. Szyjko, Nowy wymiar dialogu energetycznego UE-Rosja z perspektywy priorytetów polskiej prezydencji, in: A. Bryc, A. Legucka, A. Włodkowska-Bagan, eds., op. cit., p. 330.

147 E. Kużelewska, op. cit., p. 301.

148 Ibid, p. 308.

149 The EU's only initiative in Georgia was the European Union Monitoring Mission in Georgia (EUMM), which resulted in the cessation of armed violence, a relative stabilisation and the respect of human rights. A. Ciupiński, op. cit., pp. 141-143.

150 J. Korwin-Mikke, GUAM w Eurazji, “Najwyższy Czas”, R. XVII, no. 21 (836) May 27, 2006, p. XX. 
not stable enough yet, and remain strongly susceptible to external influence. Russia alone may use various instruments of pressure on GUAM members (by supporting separatist movements in Georgia ${ }^{151}$ and Moldova, acting on its dominant position as exporter of energy resources to which Moldova and Ukraine are already in huge debt, lobbying through Russian companies which played a key role in the privatisation of local energy sectors, or by inciting revolt among the local Russian diasporas, especially in Ukraine ${ }^{152}$ ). Only unambiguous support from the West and an actual, realistic promise of membership in the EU and NATO may help these countries to establish state structures independent from Russia. However, none of the regional or global powers can guarantee the existence of GUAM, as they all cooperate with this organisation on a temporary basis, only to obtain as much profit as possible for themselves. GUAM gradually lost its credibility in the eyes of the EU as an organisation whose goal, according to the Kyiv Declaration, was "to strengthen democracy, enforce the rule of law and respect basic human rights and liberties"153. The 2007 events in Ukraine and Georgia, and of 2009 in Moldova, as well as the consistent reinforcement of Ilham Aliyev's dictatorship in Azerbaijan, all prove that these declarations too were meaningless.

All joint economic initiatives undertaken by GUAM states with a view to connect their region with the global economy will end in merely partial success as long as the issues of Transnistria, Abkhazia, South Ossetia and Nagorno-Karabakh remain unresolved. The constant activity of the Minsk Group, as well as the lack of a significant reaction by Western countries to the events of August 2008 might lead to ethnic animosities spilling over into other countries in the future, which would result in the strengthening of Russia's position in post-Soviet territories.

The plans and goals of various GUAM members also differ significantly. Some Moldovan politicians see their country's membership in GUAM as a step towards EU accession. As one of the poorest European countries, Moldova requires support in both social and economic matters. Nevertheless, according to several Moldovan experts, Chisinau has no real possibility to distance itself and become independent from the countries, with which it is tied geopolitically and economically, which predominantly means the Russian Federation. At the beginning of GUAM's existence, Moldova had avoided getting involved in the organisation's activities. After assuming his presidential post in 2001, V. Voronin not only stressed the importance of cooperation with Russia, but even went on to declare the desire to join the

151 Russia managed to achieve its goal by preventing the rebel provinces from being re-merged with Georgia. Russia recognised Abkhazia and Ossetia as independent countries (August 25, 2008 Council of the Federation, August 26- the President) and established special security zones to protect the new states against Georgia's retaliation. Even Moscow's closest allies, including China and certain post-Soviet, abstained from doing the same.

152 Among the examples of such policies are: the status of Russian language in the Autonomic Republic of Crimea and the attempt to include Ukraine in the Union State.

153 D. Kałan, op. cit. 
Union State of Belarus and Russia ${ }^{154}$. Since 2005, Moldova has tried to play a leading role in the organisation (albeit with several pauses), while at the same time, the word GUAM means nothing to Moldovan society ${ }^{155}$. The majority of Moldovan citizens are not interested in this organisation, and some political science experts even question its future existence ${ }^{156}$. Moldova's flirtation with GUAM proved a temporary tryst that was soon thwarted as Chisinau seeks to avoid confrontation with Moscow. Recently, interest in GUAM was slightly revived, but "no one knows what the future will bring to this strange country, the creation of which was much more due to coincidence than to an actual will of a nation"157. There is no guarantee of Ukraine and Georgia staying in GUAM in the future, as they may always put an end to its existence as soon as they notice some better opportunities for themselves in other blocs and pacts. Victor Yanukovich had called GUAM "an organisation devoid of sense" even before the second round of the presidential elections in Ukraine ${ }^{158}$. His ascension to power led to the marginalisation of the organisation in national policy. As Agnieszka Myśliwy remarked, the most important factor consolidating GUAM, if not its raison d'être, is Azerbaijan's (previously also Uzbekistan's) abundance in oil and gas ${ }^{159}$. However, the desire to sell gas at market prices and obtain potential revenues from transit tolls could equally lead to the weakening of cooperation within the organisation (the example of "Nabucco" may just be a prelude...). The real chance for GUAM members lies in the role of intermediaries in the trade between Europe and the rapid drive for prosperity of South-East Asia and, more notably, in China and India. Another of GUAM's advantage derives from its geographic location, which may be used by the organisation for the transit of resources, as well as to gain control over the transit of other commodities through the implementation of a complex development plan involving roads and railways, airports and transport infrastructure. If GUAM were to manage liberating itself from Russian influence and bring internal stability, it could become, with its own free trade area and support from reliable allies, an alternative for former USSR republics also struggling with Russian domination. However, this would require its members to adhere strictly to a precise plan of cooperation without succumbing to external pressure ${ }^{160}$.

Unfortunately, a number of experts hailing from GUAM member states give the organisation a low chance of success. According to Moldovan journalist Victoria Dunaeva, GUAM "has become an odd organism, which can neither fully begin to

154 A. Myśliwy, op. cit., p. 139.

155 V. Dunaeva, op. cit., p. 79.

156 "Nezavisimaya Gazeta" - GUAM chce zostać unijna dyspozytornia gazu...

157 As quoted by V. Dunaeva, op. cit., p. 80.

158 D. Kałan, op. cit. As previously demonstrated, energy issues led him to reevaluate his policies and decisions.

159 A. Myśliwy, op. cit., p. 140.

160 Ibid, p. 141. 
live nor does it intend to die"161. When asked in 2009 about the organisation's future, the President of Moldova V. Voronin said that GUAM was devoid of prospects ${ }^{162}$. Azeri commentators appear pessimistic as well. The political scientist Zaur Gasimov belives that GUAM has been resembling the CIS for a few years already. The meetings at different levels all prove to be unsuccessful, as the elites of its member states have divergent interests. The primary aspects of GUAM-democratisation and integration with NATO-are no longer priorities for the elites in Kyiv, Chisinau ${ }^{163}$ or Baku ${ }^{164}$. According to another Azeri expert, Arif Yanusov, GUAM will survive as long as Russia "scares away its neighbours ... with aggressive rhetoric, with the obvious desire to re-establish its dominance and the suffocation of democratic processes." Both current realities and the prognoses do not bode well for this organisation.

\section{GU(U)AM - from declarations to reality}

The aim of the lecture is to outline the functioning of GUUAM, the organization which originated in 1997 and associates Georgia, Ukraine, Uzbekistan (until 2005), and Moldova. The author's intention was to answer several vital questions - was it possible to accomplish the desired long-term goals of the member states aiming at limiting the influence of Russia in the region and declaring the intention to join the European Union and NATO? Was it possible to accomplish the declared, common strategic interests such as regulation of region destabilizing conflicts, accomplishment of common economic goals, deepening cooperation in power engineering industry, cooperation in military activities through an organization uniting countries on such diversified levels of political transformation, with poorly functioning economies inherited after the Soviet Union, and Russian military bases on their territories? The author identifies entities that really care for GUUAM's survival and its further dynamic actions. She also poses questions on future prospects of development of this organization, trying to find the answer to the question why Poland has so much engaged on behalf of GUAM.

Translated by Jakub Perliński

161 V. Dunaeva, op. cit., p. 78.

162 A. Lemieszonek, op. cit.

163 Moldova was advocating integration with the EU.

164 Azerbejdżan będzie drugim Iranem (Interview with Dr. Zaur Gasimov 29 I 2011), http://www. portal.arcana.pl/Gasimov-azerbejdzan-będzie-drugim-iranem,598.html (accessed on 14 IV 2012). 